\title{
Memories' fragments of of deported women: adaptation and life in Kazakhstan
}

\author{
DOI: 10.31551/2410-2725-2019-5-2-232-247
}

\section{Saktaganova Zauresh Galimzhanovna}

$\mathrm{PhD}$ in HistoricalSciences, director of the Center for Ethnocultural and Historical Anthropological Studies, professor of the Chair of archeology, ethnologies and Native history of Karaganda State University named after E. A. Buketov Karaganda, Kazakhstan. E-mail:zauresh63@mail.ru

\begin{abstract}
One of the most popular research topics from the 1990s, becomes the problem of deportation processes in the Soviet Union. Russian researchers claim that only internal deportations in the USSR covered more than 6 million people. The deportations of ethnic groups to Kazakhstan were carried out in several stages in the period of the 1930s - 1940s. Among the deported people, a significant proportion were women. In this article, the subject of the study will be memories of deported women. A brief historiographic review points out that, despite some knowledge about deportation's problems, the gender aspect of deportation processes has not yet become the subject of a special study. The basis of the study were fragments of deported women's memories, recorded in different years by journalists, published in newspapers, laid out on websites and collected during interviews during the implementation of the project of KARSU researchers about women from Kazakhstan during the Great Patriotic War. While composing research project various common scientific (methods of empirical research, methods of theoretical knowledge, general logical methods and research technique) and special historical methods (comparative historical method, analysis of memories of various deported peoples, macro- and microhistorical approaches, etc) were incorporated. Among many female memories were selected fragments of deported people's memories: Poles, Germans, Chechens, Ingush. The article notes, that memories about the deported past differed depending on a number of factors: age of the narrator, his intellectual and emotional experience and other things. But in these fragments you can see common features: "a feeling of repression poured into words and plots that created the language of injury. "Total of these fragments summarized by the author in conclusion of the article.
\end{abstract}

Key words: Kazakhstan history of the twentieth century, deportations of people, women's memories, deportation of Poles, deportation of Germans, deportation of Chechens, deportation of Ingush people.

\section{Депортацияланған әйелдер естеліктерінен үзінділер: бейімделу және Қазақстандағы өмір}

\section{Сақтағанова Зауреш Ғалымжанқызы}

Тарих ғылымдарының докторы, Е.А. Бөкетов атындағы Қарағанды мемлекеттік университеті этномәдени және тарихи-антропологиялық зерттеулер Орталығының директоры, археология, этнология және Отан тарихы кафедрасының профрессоры, Қарағанды, Қазақстан. E-mail: zauresh63@mail.ru

Аңдатпа. 1990 жылдардан зерттеушілік тақырыптардың ішіндегі ең танымалдысы Кеңес Одағындағы депортациялық үрдістер мәселесі болды. Ресейлік зерттеушілер тек КСРО-ның ішіндегі депортацияға 6 млн.-нан астам адам қамтылғандығын айтады. Қазақстанға этникалық топтардың депортациялануы 1930-1940 жылдар аралығында бірнеше кезеңдермен жүзеге асырылды. Депортацияланған халықтар ішінде басым көпшілікті әйелдер құрады. Аталған мақалада зерттеудің пәні депортацияланғанәйелдердің естеліктері болады. Депортация мәселесінің белгілі бір деңгейде зерттелуіне қарамастан қысқаша тарихнамалық шолу депортациялық мәселелердің гендерлік аспектісі арнайы зерттеудің пәні болмағандығын көрсетеді. Зерттеудің негізі ретінде әртүрлі жылдары журналистердің газеттерде жариялаған, ғаламтор сайттарында орналастырылған және ҚарМУ зерттеушілерінің Ұлы Отан соғысы жылдарындағы Қазақстан әйелдері туралы жобасы аясында жүргізілген сұхбаттасу барысында жиналған депортацияланғанәйелдердің естеліктерінің үзінділері алынды. Зерттеудің барысында жалпығылыми әдістер (эмпирикалық зерттеу әдістері, теоретикалық таным әдістері, жалпылогикалық әдістер және зерттеудің тәсілдері) және арнайы тарихи әдістер (әртүрлідепортацияланған халықтар естеліктерін меңгеру мен талдау кезінде салыстырмалытарихи әдіс, макро- және микротарихи тәсілдер және т.б.) қолданылды. Көптеген әйелдердің естеліктері ішінде депортацияланған халықтар: поляк, неміс, шешен, ингуштер естеліктерінің үзінділері таңдап алынды. Мақалада депортацияланған өткен туралы естеліктер көптеген факторларға: әңгімелеушінің жасына, оның интеллектуалды және эмоционалды тәжірибесіне 
және басқасына байланысты ерекшеленгендігі атап көрсетіледі. Бірақ бұл естелік үзінділерінен ортақ белгілерді көруге болады, ол: «қуғынға ұшырау сезімінің жарақат тілін тудырған сөздер мен сюжеттерге ұласқандығы». Бұл естелік үзінділеріне тән жалпылылық автормен мақаланың қорытындысында түйінделген.

Түйінді сөздер: XX ғасырдағы Қазақстан тарихы, халықтар депортациясы, әйелдердін естеліктері, поляктар депортациясы, немістер депортациясы, шешендер депортациясы, ингуштер депортациясы.

\section{Фрагменты воспоминаний депортированных женщин: адаптация и жизнь в Казахстане}

\section{Сактаганова Зауреш Галимжановна}

Доктор исторических наук, директор Центра этнокультурных и историко-антропологических исследований, профессор кафедры археологии, этнологии и Отечественной истории Карагандинского государственного университета им. Е.А. Букетова, Караганда, Казахстан, E-mail:zauresh63@mail.ru

Аннотация. Одной из наиболее популярных исследовательских тем с 1990-х годов, становится проблема депортационных процессов в Советском Союзе. Российские исследователи утверждают, что только внутренними депортациями в СССР было охвачено более $6 \mathrm{mлн.}$ человек. Депортации этнических групп в Казахстан осуществлялись в несколько этапов в период 1930-х - 1940-х годов. Среди депортированных народов значительную часть составили женщины. В данной статье предметом исследования станут воспоминания депортированных женщин. Краткий историографический обзор свидетельствует, что, несмотря на определенную изученность проблемы депортаций, гендерный аспект депортационных процессов так еще и не стал предметом специального исследования. Основой исследования стали фррагменты воспоминаний депортированных женщин, записанные в разные годы журналистами, опубликованные в газетах, выложенные на интернет-сайтах и собранные во время интервьюирования в ходе реализации проекта исследователей КарГУ о женщинах Казахстана в годы Великой Отечественной войны. При написании исследования были использованы различные общенаучные методы (методы эмпирического исследования, методы теоретического познания, общелогические методы и приемы исследования) и специальные исторические методы (сравнительно-исторический метод при изучении и анализе воспоминаний различных депортированных народов, макро- и микроисторический подходы и др). Среди множества женских воспоминаний были отобраны фррагменты воспоминаний депортированных народов: поляков, немцев, чеченцев, ингушей. В статье отмечается, что воспоминания о депортированном прошлом различались в зависимости от ряда факторов: возраста рассказчика, его интеллектуального и эмоционального опыта и прочего. Но в этих фрагментах можно увидеть общие черты: «ощущение репрессированности выливалось в слова и сюжеты, создававшие язык травмы». Общее этих фрагментов резюмируются автором в заключение статьи.

Ключевые слова: депортации народов, история Казахстана XX века, женские воспоминания, депортация поляков, депортации немцев, депортация чеченцев, депортация ингушей.

УДК/ UDC 94.(574.42)

\section{Фрагменты воспоминаний депортированных женщин: адаптация и жизнь в Казахстане}

\section{3.Г. Сактаганова}

Введение. Одной из наиболее популярных исследовательских тем, начиная с 90-х годов прошлого века, становится проблема депортационных процессов в Советском Союзе. Общеизвестно, что депортации в СССР осуществлялись по двум основным признакам: социальный, когда

1 Статья выполнена в рамках проекта КН МОН РК: «Великая Отечественная война и женщины Казахстана на фронтах и в тылу: женские истории и повседневность». ИРН проекта АР05131992 
насильственному выселению подвергались по определению власти, «социально опасные элементы» (казаки, кулачество и другие), и этническому, когда насильственное переселение охватывало, по определению большевиков, «политически неблагонадежные» народы. Характеризуя социальные и этнические депортации с 1920-х по 1950-е годы, российский исследователь П. Полян выделил 52 депортационные кампании и 130 депортационных операций в рамках этих компаний (Полян, 2001).

А из 52 депортационных кампаний 38, или 73\%, являлись этническими. В целом российские исследователи утверждают, что только внутренними депортациями в СССР было охвачено более 6 млн. человек (Сталинские депортации, 2005: 13). Депортации народов в Казахстан осуществлялись в несколько этапов, причем они начались в период 1930-х годов, продолжались в следующем десятилетии, в 1940-х годах. Среди депортированных народов значительную часть составили женщины. В данной статье мы остановимся на фрагментах женских воспоминаний депортированных. Воспоминания о депортации были оставлены в публичном пространстве в период перестройки (в 80-е), да и в 90-е годы XX века преимущественно мужчинами; как отмечают исследователи, «преодолеть женское молчание было трудно»: о наиболее драматичных эпизодах женщины умалчивали осознанно, это было проявлением женской немоты, которая была традиционной в обществе постсоветского пространства в прошлом столетии (Гучинова, 2008). Но материалы женских воспоминаний не только позволяют проиллюстрировать процессы насильственного переселения, они позволяют увидеть эти события женским взглядом, который отличается от мужского. Анализируя тексты воспоминаний, интервью, можно выявить некоторые закономерности восприятия женщинами депортационных процессов, воссоздать женское восприятие депортаций как отдельной страницы этих трагических процессов. Необходимость проявить все аспекты депортаций не только на основе архивных материалов, нарративных источников, но на основе устной истории, воспоминаний актуализирует проблему, вынесенную в данной статье, тем более что с годами количество свидетелей, участников этих событий катастрофически уменьшается.

Материалы и методы исследования. Ряд концептуальных положений из работ исследователей 1960-1980-х годов, ставших сегодня классическими, легли в основу многих современных публикаций о депортациях. Р. Конквест, в частности, этнические депортации военного времени в СССР рассматривал как естественное продолжение колониальной политики царской России, облегченное компактной конфигурацией и «сухопутностью» Российской Империи (Conquest, 1960). Исследователь П. Полян считал, что подход царского правительства к «враждебно-подданным» во многом предвосхитил страшные черты депортационнной политики советского государства (Полян, 2001). На первом этапе депортации (1920-1930-е годы) в СССР были осуществлены преимущественно с пограничных территорий страны; началась серия акций «по обеспечению безопасности границ и приграничных территорий» посредством их освобождения по этническому признаку от «неблагонадежных», с точки зрения советского руководства, элементов. Второй этап депортаций охватывал военный период (1939-1945 годы);для депортированных народов на этапе военного времени А. Некрич использовал термин «наказанные народы» (Некрич, 1978).

Методологическим посылом статьи стала концепция А. Людтке (Людтке, 1999), где особое внимание направлено на изучение микроистории отдельных 
рядовых людей или их групп; желание понять историю как многослойный процесс, который воспроизводится и, в первую очередь, трансформируется теми, кто является одновременно и объектами истории, и ее субъектами. Воспоминания позволяют формировать историю повседневности, которая проявляет особый интерес к микроисторическим явлениям и процессам, к истории малых социумов и исторических коллективов, а также к семейной и биографической истории. Ее цель - сделать так, чтобы «обычные люди обрели в истории собственные голоса и лица». Эти «голоса и лица» проявляются и во фррагментах воспоминаний депортированных женщин.

При написании статьи были использованы различные общенаучные методы: методы эмпирического исследования - сравнения, описания, наблюдения во время интервьюирования; методы теоретического познания; общелогические методы и приемы исследования - анализа и синтеза, аналогии, системного подхода. Использовались и специальные исторические методы: сравнительно-исторический метод при изучении и анализе воспоминаний различных депортированных народов, синтез макро- и микроисторических подходов, поскольку макроисторический подход отражает изменения в целом в развитии общества, а микроисторический подход позволяет проследить влияние макрособытий на тактику выживания, поведенческие стереотипы депортированных народов.

В статье использованы воспоминания депортированных женщин, как записанные в разные годы журналистами, опубликованные в газетах, выложенные на интернет-сайтах, так и собранные во время интервьюирования в ходе реализации проекта исследователей КарГУ о женщинах Казахстана в годы Великой Отечественной войны.

Обсуждение. С момента своего осуществления в 1930-х годах и до конца 1980-х принудительные миграции были в СССР одной из самых табуированных тем: из научного и общественного знания были исключены любые сведения о депортациях и депортированных народах. Первые исследования, посвященные этим вопросам, появились на Западе: в 1960 году в США вышла книга Р. Конквеста с хронологией и статистикой депортаций народов (Conquest, 1960), но она была незнакома советскому читателю. В общем контексте сталинских репрессий об этнических депортациях писал А. Солженицын (Солженицын, 1989). А. Некрич в конце 1970-х годов этнические депортации в СССР впервые рассматривал как целостную, научную проблему (Некрич, 1978). В российской историографии конца XX - начала XXI веков следует отметить публикации Н.Ф. Бугая (Бугай, 1995), В.Н. Земскова (Земсков, 2005), П. Полян (Полян, 2001) и др. Казахстанская историография депортаций активно разрабатывалась К.С. Алдажумановым, Ж.Б. Абылхожиным, Г.В. Кан, Г. Бельгер и другими авторами (Депортированные в Казахстан, 1998). Опубликованы многотомники документальных сборников по депортациям (Из истории депортаций, 2014).

В целом можно согласиться с исследователем Э.Б. Гучиновой, что тема выселения народов и их виктимизация становятся популярными для историков, журналистов и издателей с постперестроечных лет для одних народов и не стали представлять интерес для других (у которых не было своей фрормы государственности и других фрорм институализации групповых интересов) (Гучинова, 2008). Гендерные же аспекты депортационных процессов фактически до сих пор не стали предметом специальных исследований в исторической науке, и, если российская историография в 
целом сделала гендерную проблематику одной из ведущих в XXI веке, то отечественные историки лишь делают первые шаги.

Результаты. Абсолютно однозначно, что процессы депортации стали травмой для депортированных, и как психологическая травма, и как эмоциональная, и как культурная. Культура преодоления травмы через глубокое повествование о ней пришла на смену идеологии «преодоления прошлого» относительно недавно, считают исследователи (Гусейнов, 2008).

Автор Эльза-Баир Гучинова опубликовала интересную статью с женскими воспоминаниями о депортации калмыков и армян. Анализируя сочинения школьников о депортации калмыков, написанные в 1993-2004 годы на основе бесед со старшими родственниками, дневник армянской девочки, который она вела во время депортации, а также устные рассказы калмычек и армянок, автор изучает грамматику и лексику травмы депортированных женщин. И приходит к ряду выводов. Нельзя не согласиться с Э.-Б. Гучиновой, что «тоталитарный опыт насилия не позволял выразить его дискурсивно и языком репрезентации становился язык травмы. Рассказы о болезненном прошлом различались в зависимости от многих факторов: пола и возраста рассказчика, историко-культурного и политического контекста, от обстоятельств повествования и прочего. Но в текстах травмированной памяти, считает автор, можно увидеть общие черты: «ощущение репрессированности выливалось в слова и сюжеты, создававшие язык травмы, в грамматические конструкции, отражавшие потерю субъектности» (Гучинова, 2008). «Вспоминая давнее прошлое, рассказчики подсознательно возвращались в сталинское общество и воспроизводили свой зависимый статус людей, удел которых - претерпевать чужие действия, быть жертвой чужих решений» (Гучинова, 2008).

Некоторые закономерности, выведенные в данной статье, подтверждаются фррагментами приведенных нами женских воспоминаний. Первое «преобладающее использование «пассивных» страдательных грамматических конструкций с неопределенным субъектом в сочетании с безличной глагольной формой»: в воспоминаниях о начале депортации или положении репрессированных на спецпоселениях практически всегда используется неопределенная фрорма глагола, хотя уже сейчас точно известно на ком персонально лежит ответственность за эти депортации. Но все равно в воспоминаниях звучит так: «объявили о переселении», «на сбор дали три дня», «разрешалось брать». Второе - «отсутствие приватности человека и публичность интимных процедур». Для женщин эта тема всегда болезненная, но они говорят об этом: «естественно никаких условий там не было, только в углу стоял бочок для нужд». Третье - «множество выражений отражающих нечеловеческий статус репрессированных». Часто в воспоминаниях женщины говорят об отношении к себе, депортированным, не как к людям: «телячьи вагоны», «в нечеловеческих условиях», «загнали, как скот», «обращались как с животными». Эти три характеристики нам кажутся совпадающими во всех воспоминаниях без исключения. Они проявляются ярко и сразу обращают на себя внимание. Но есть, на наш взгляд, еще ряд закономерностей.

Рассмотрим, как через фррагменты воспоминаний о женщинах и женских воспоминаний языком травмы излагаются события насильственного переселения, адаптации и выживания женщин в Казахстане.

Депортация поляков, май 1936 года.Воспоминания Станислава Кулаковского о рассказах своей матери: депортировали маму, как рассказывала она, с семьей старшего брата из Украины в село Подольское Северо-Казахстанской области. В конце мая 1936 года объявили о 
переселении, на сбор дали три дня. Разрешалось брать с собой все, говорила мама: коров, кур, коз, лошадей. Через три дня подогнали подводы и повезли на железнодорожную станцию в сопровождении верховых милиционеров. Утром прибыли на станцию прямо на погрузку. На путях стояли телячьи вагоны с раздвижными дверьми, четыре узких окна вверху. Загружали людей по 10-15 семей в один вагон. С собой в вагон разрешили взять только постель, остальные вещи были сложены в конце эшелона. Мама рассказывала, что в ходе посадки женщины плакали, кричали, а особенно перед самой отправкой плакали не только женщины, дети, старики, прощаясь с родным домом, с родными краями, но и взрослые мужчины. В начале июня поезд прибыл на станцию Тайнча в Северном Казахстане. Семью разделили: по распределению на железнодорожной станции Тайнча отца направили в точку № 2, впоследствии село Донецкое; маму - в точку № 4, названную позже село Подольское. От станции Тайнча переселенцев отвезли за 20 километров в степь. Везли степной дорогой, кругом ковыль, в небе жаворонки, целые поляны земляники, ни деревца, ни тени, ни строений. Выгрузили в голой, бескрайней степи у единственного колодца, где были вбиты лишь колышки. На обустройство дали три дня, установили палатки, но практически сразу же переселенцы стали строить землянки. В одной землянке проживали две-три семьи, примерно 12-20 человек. Для того, чтобы приготовить кушать, копали яму из дерна делали печку. Топили бурьяном и кизяком, который собирали в степи и неподалеку от старых сел. На четвертый день сбор у комендантской палатки, сразу предупредили, что зимы здесь очень суровые, морозы до 40-50 градусов, страшные бураны, каких на Украине никогда не видели. На работу надо было выходить всем, кроме кормящих матерей. Здесь же была поставлена задача: построить жилье, школу, больницу, сарай для скота. Строили из самана. Мама вспоминала, что в первые месяцы умирало очень много людей, особенно детей. Хоронили родных и близких в степи, не имея возможности поставить крест, не из чего было. Рядом с селом был казахский аул, соседи нечасто наведывались, опасались властей, да и языковой барьер мешал. Зато дети быстро наладили отношения, наши дети учили казахских русскому языку, а они угощали куртом и баурсаками. Казахи приезжали в село (спецпереселенец не имел права без пропуска выходить за пределы села), и переселенцы меняли свои вещи на хлеб, на продукты питания, строительные материалы. Переселенцев местные жители не обижали, наоборот, старались хоть чем-нибудь помочь. Относились дружелюбно. Мальчишки, познакомившись со сверстниками-аульчанами, дружили, поддерживали отношения. Мама собирала молоко, делала сыр, масло для продажи в Тайнче или у проходящих поездов. Оставив детей, ночью 20 километров пешком шла к поезду и продавала. Также обратно возвращалась пешком домой, не оглядываясь, потому что хорошо знала, что ее никто не подвезет. (Чемодан историй, 2017).

Депортация немцев, сентябрь 1941 года.Воспоминания Фиттель Ирмы, жительница села Тельманское Карагандинской области: «Нас выселили 23 сентября 1941 года, из села Ольгино, Запорожской области. Нам сообщили о том, чтобы за 24 часа мы собрались и отправились в путь. С собой можно было брать только продукты питания, запасом на неделю, теплую одежду и постель, больше ничего не разрешили. Нас было в семье на тот момент четверо: мама я и двое братьев. Отца расстреляли еще в 1938 году, обвинив в шпионаже. Всех мужчин нашей семьи отправили на трудовые работы раньше, поэтому депортации подверглись женщины и дети. Нас спустя 24 часа отправили на 
станцию, оттуда отвезли на порт в Бердянск. Само переселение было страшное: я видела, как умирают близкие и родные мне люди. Помню, как брат умер по пути в Казахстан, у него было воспаление. Пришли санитары и забрали его. Мама рассказывала, что его не похоронили. Очень долго оплакивала, говорила, что его кости остались на холодной, чужой земле. И таких случаев было много. У тети умер грудной ребенок. У нее пропало молоко, и ей нечем было его кормить. Страшное время было. Со временем мы, конечно, привыкли и к местному климату, постоянным ветрам и буранам. Спустя год, переехав с Акмолинской области, обжились на 6 поселке, мы молились, каждый день лишь бы все обошлось.

Везли нас в нечеловеческих условиях, всех загнали, как скот в грязные палубы. Через две недели пути мы прибыли в Ейск. Спустя пару дней нам объявили, что необходимо отправляться на железную дорогу... и нас увезли в неизвестном направлении в товарном вагоне. Естественно никаких условий там не было, только в углу стоял бочок для нужд. Мы сидели друг на друге, быстро затекали ноги, встать было невозможно. Поезд иногда останавливался примерно раз в два дня, разрешали выйти на улицу попить воду, очень редко давали хлеб. Когда мы прибыли в Казахстан, было уже очень холодно, ноябрь месяц, одежда, которую мы привезли с собой, не подходила по сезону. Нас изначально привезли в Северный Казахстан, Акмолинскую область, спустя две недели переселили в Карагандинскую область. Привезли на грузовиках на «точку 22». Всех расселяли по землянкам, у живших там спецпереселенцев. Нас заселили к семейной пожилой паре, землянка была очень маленькой, всего одна комната, печка стояла посередине комнаты. В доме было очень грязно, мы жили 6 человек в одной комнате. Землянки, в которых проживали спецпереселенцы, были сделаны из самана, учитывая, что площадь была небольшая, в домах было тепло. Приходилось добывать пищу, обменивать свою одежду, привезенную из дома, на кизяк у местного населения. Рацион питания был очень скуден, первое время питались запасами, которые были привезены из дома. Моя мама умела хорошо шить и вязать, взамен на это получала молоко, картошку, так и перебивались. Сам поселок был бедный, и даже местные жители были на грани выживания. Хозяева, у которых мы жили, были очень добрые люди и пытались нам всячески помочь, зимой мы растапливали снег, и эту воду использовали для всех нужд, этот же талый снег мы пили, готовили еду. Не знаю, как мы пережили эту зиму, весной пошли работать на скотные дворы. Жить в таких условиях было невозможно: ничего не было, даже помыться нечем было. За время переезда у всех были вши, от грязи лица покрылись лишаями. В холодной голодной степи пытались найти хоть что-то: веточку, палочку, чтоб печь протопить.

Питались мы первые недели после прибытия тем, что привезли с собой. Потом стали обменивать какие-то вещи на еду. Да и семья, у которой жили, никогда нас не обделяла. Всегда сажали за стол. Ели в основном галушки. Помню, один раз мы с братом зайца поймали, столько счастья было, летом уже стали ловить рыбу, переехали в другой совхоз, посадили там огород. А первый год зимой с голоду пухли. Как вспомню эту боль в животе. Бывало и по два, три дня ничего не ели. Только талый снег пили. Воды в деревне тоже не было. В поле ходили, снег раскапывали, там какие корни, травку найдем, из этого суп варили. Очень тяжело было пережить первую зиму. Лекарств никаких не было. Первый год, когда мы приехали, брат сильно заболел. Температура высокая была, мы даже не знали, как лечить его. Ночью он не спал, горел весь. Мама поила его чаем из веточек, которые собирали. Да вот и все лекарство, но 
он все равно умер. Потом уже мы стали собирать травы в лесу, сушили листья земляники, малины, собирали шиповник, боярышник. Рыбий жир собирали. Первый год был самым худшим, на второй год мы стали обживаться.

Мамина сестра выяснила, что на 6 поселке Осакаровского района условия благоприятнее, чем в тех которых мы сейчас проживаем. Но для того чтобы выехать за пределы колхоза, необходимо было заплатить налог и получить разрешение. Из оставшихся денег, которые мы привезли с собой, оплатили этот военный налог и переехали на 6 поселок. Близ села находилась небольшая лесополоса, где можно было заготовить дров. И этот поселок был более зажиточный, в котором проживали украинские спецпереселенцы. У них были дома с крышами, большими окнами. Крыши были сделаны из камыша. Также близ поселка протекала речка, на которой мы ловили рыбу, мне уже тогда было почти 15 лет, я считалась взрослой, и поэтому присматривала за всей малышней. Перебрались в Карагандинскую область. Здесь и остались жить.

Несмотря на помощь казахского населения, которые оказывали всяческую поддержку, положение оставалось плачевным. Так маме и всем детям приходилось работать на поле в летнее время по 12-15 часов в сутки, чтобы прокормить свою семью. На 6 поселке мы посадили около дома огород. От людей получали навоз - рассыпали, выращивали - все работали, все! Кизяк лепить летом, месить и топить чтобы зимой: сушить, поворачивать его, летом надо было огород полоть, собирать кустарник на веники, на зиму наломать, насушить, двор подмести, в общем, работа была целый день. Потом тетя Лиза стала работать на свиноферме, и мы пасли летом свиней. Спустя еще один год я с мамой пошла работать на поле. Там работали с утра до ночи. Очень тяжело было, но спасибо, что приняли и приютили нас немцев и не дали нам умереть с голоду местные жители. Тетя Лиза рассказывала что паек, который им давали в трудармии, был очень маленький. Давали 8 кг муки на месяц, когда план не выполнялся, а план был большой. Также каждый день давали 400 грамм хлеба черный, как кирпич, и баланда из капустных листьев.

Вся одежда, которую привезли, очень быстро износилась. Да и когда мы приехали в Казахстан, в ноябре, было очень холодно. Мама начала из того, что стала шить одежду, собирать какие-то лоскутки. Мы с собой еще привезли швейную машинку, которая и помогла нам выжить. Мама очень хорошо шила: из простыней шили косынки, вышивала на них и обменивали на продукты. На второй год депортации стали вязать из шерсти носки, варежки, шапки, так и перебивались. Каждый кусочек ткани был на вес золото. Семья стариков, у которых мы жили первый год, дали нам телогрейку теплую и одни валенки на всю семью были. Вот это по очереди и носили.

Школы были, даже в первом поселке была школа. Почти никто (очень мало из наших приехавших туда, кого привезли в это село) не послали своих детей в школу. Потому что, во-первых, холодно, голодно, многие говорили: «Еще мы будем детей гонять в эту школу, пусть сидят хоть немножко в тепле». Но мама же сказала: «Нет! Он пойдет в школу». И отвела моего брата в первый класс. Реву было - неимоверно много! И сколько бы времени не прошло, но все равно он не хотел: все чужие, никого нет, в школе тоже холодно. Но мама его заставила. Я уже в школу тут не ходила, помогала маме по хозяйству, работала. Брат закончил автошколу после того как отучился в школе». (Интервью с Фиттель, 2019)

Воспоминания Кристины Бишель, депортированная семья из Краснодарского края: «Нас привезли в Казахстан, на станцию Щербакты. 
Выгрузили в страшный мороз и окоченевших, голодных повезли по деревням. Попали мы (вся семья) в деревню Александровка. Встретил нас председатель сельсовета Сологуб и взял к себе домой. У него было двое детей, и уже была назначена свадьба дочери, но он отложил свадьбу. Он вообще был очень добрым человеком. Никогда не садился за стол без нас. Он старался дать нам какие-нибудь вещи, ведь мы были почти раздетыми. И люди в деревне относились к нам по-доброму».

Вспоминала Фрида Лауер, с крымского хутора Нурали: «Привезли в Казахстан. Разобрали нас по казахским домам. Казахи ни слова не понимают, ни на русском, ни на немецком, и мы ни слова по-казахски. А с нами была наша бабушка Лиза, она немного понимала по-татарски. Казахский и татарский языки родные - вот бабушка нам кое-что и переводила. В этой деревушке ели мы хлеб пока старшие братья работали. За день работы им давали лепешку хлеба. Они ее приносили домой и мы делили лепешку. Работы было мало, а без работы не было и хлеба», Вскоре ее старшие братья, как и большинство немцев-спецпереселенцев, нашли работу в местном колхозе. Однако трудились там недолго, были мобилизованы в так называемую трудовую армию».

Воспоминания Луизы Экфурт: «У мамы было двое детей, брат мой 1937 года рождения, сестра родилась 1-го августа, а 9-го сентября их выслали. С грудным ребенком вот этот путь проделала. Привезли на стацию Колутон Акмолинской области, сгрузили нас. Что запомнилось: стоят казахи, повозки, запряжённые быками и верблюдами. От этой станции Колутон до Воробьевки разнарядки были, кого куда, ехали на повозке на быках. В этом селе в основном жили русские и украинцы. Такие деревенские избы - комната, кухня, сенцы и дальше постройки хозяйственные. Там своя семья и эта семья восемь человек. Хорошо было, что печка топилась на две комнаты, все же они были в тепле. Папиных сестер забрали в трудармию, папу тоже забрали в трудармию. У меня тети были в Сибири, строили железную дорогу. Жили они в бараках, все это продувалось, одевать было нечего. Весна наступала, они в воде. Люди умирали, просто мор было. Зимой хоронить нельзя, к весне оттаивало, рыли рвы, трактором ров общей братской могилы. Оскорбляли: и фрашисты, и фррицы. Не знаю, взрослым, наверное, это было тяжелее пережить, а мы-то, дети, все равно в одном классе учились, дети как-то быстрее сходятся. Было обидно, конечно, но что делать. Я сколько себя помню, уже могла ходить в детский сад. Потом в школу. Писать не на чем было, тетрадки были из чего-то, даже иногда из газет сшивали что-то, на полях писали. Какие у нас тогда были учителя - это надо отдать должное, они сплачивали. В этом селе, где мы жили, люди не были агрессивными. Прошел период, потом уже были все вместе, уже не разделялись, где казахи, где украинцы, где русские, где немцы. Видимо, общее горе, оно как-то сплачивало людей. Мне было всегда удивительно потом уже, когда я задумалась, почему у нас в Казахстане иностранный язык был немецкий. В доме у нас только на немецком говорили, тем более, что очень плохо знали русский. Мама, мне кажется, русский понимать понимала, а говорила все время по-немецки.

Вообще жили плохо, не только те, что приехали, жили и местные плохо, тот же голод был, лишнего не было. Те вещи, которые у них были, они на продукты меняли. Папа у нас был трактористом. Ночь, вдруг стук в окно, бабушка выглядывает - папа у окна. Они так испугались, думали, что он дезертировал, расстреляют теперь нас всех тут. Но оказывается, нужны были трактористы и его отпустили из армии к семье. Если бы он не вернулся, мы бы 
умерли с голоду. В колхозе убирали поля, оставались там какие-то колоски, но и это не давали собирать. Если колоски собираешь, их надо сдавать непосредственно в колхозную кладовую. Они как-то пошли поздно или рано утром колоски собирать, сколько-то набрали, в это время объездчик их увидел, забрал колоски и кнутом их отхлестал. Прямо кнутом с лошади, догнал, все отобрал, кнутом стеганул и дальше поехал.

Мы построили землянку из пластов. Там целина, такие пласты вырезали и строили. Крыша была мазаная. Там жили, наверное, долго, где-то в 1959 году только купили дом, переехали в село Журавлевка и там купили нормальный саманный дом. Саман - это глина с соломой. Месили, были такие формы, эти формы заливали, заготавливали саман, из него строили дома. Ощущение постоянного холода и голода меня сопровождало почти все время, пока мы были в Казахстане. К нам в 1944 году очень много выслали чеченцев, ингушей, они были мастерами и верхнюю одежду шили. Хорошо помню, был какой-то транспортёр из брезента, вот этот транспортёр изношенный папа принес. Ингушка шила нам тапочки из этого брезента, мы были все же обутые как-то. Одежду, конечно, друг за другом носили. Из школы сестра приходила старшая, снимала с себя, одевала я и бежала в школу. Ни в чем не модничали, так, перелицовывали. Потом нам присылали посылки тети из трудармии, когда уже вернулись, в Подмосковье жили, одна работала на швейной фабрике, она лоскуты нам присылала. И вот они из этих кусков нам шили красивые платья со всякими вставками. Помню, пошла я в первый класс, у меня была холщовая сумка сшитая, тетя мне вышила ветку на этой сумке и мои инициалы. И вот с этой холщовой сумкой я ходила четыре года» (Народ выходил, 2016).

Депортация чеченцев, февраль 1944 года.Воспоминания Марьям Мусаевой, записанные ее внучкой Миланой Мальцаговой (школа N 2, 10-й класс) ст. Наурская.«В Старых Атагах объявили, что чеченцев по приказу Сталина выселяют. Всех собрали, начали увозить из села. К нам пришли трое военных и спросили, есть ли взрослые. Я сказала, что жду маму и брата, они работают в Грозном на военном заводе. Военные сказали, что их не стоит ждать, они не придут, и начали мне помогать собирать кое-что, предложили взять с собой продукты, теплые вещи. Из продуктов оказалась кукурузная мука, из теплых вещей - мамино пальто и старая отцовская фуффайка. Я настояла и взяла швейную машину «Зингер», она дала возможность выжить в Казахстане. Приехали на подводе в Грозный. Я так надеялась здесь встретить своих маму, брата. По 10-15 семей сажали в товарный вагон, а в каждой чеченской семье было по 6-7 детей. Целый месяц следовали к месту назначения. На станциях не останавливались, только на открытой местности - для того чтобы выдать умерших, где их хоронили, мы не знаем. Если и останавливались, то в тупиках, стояли сутками. Кормили кашей: одно ведро на всех. С нами в вагоне ехал дедушка, ему было 95 лет. Он очень опекал нас, детей, пытался успокоить, рассказывал, что нас ждет благодатный край, где растет кукуруза выше человеческого роста, коровы дают молока больше ведра. Старик не выдержал, умер по дороге. Открылась дверь вагона, поднялся молодой солдат, он весь дрожал от холода, его глаза были полны слез. Мне стало его так жалко, что я предложила ему отцовскую фуфайку. Дальше по пути, на остановках, солдат приносил вместе с ведром каши и буханку хлеба, спрятав ее за пазуху. Дорога была ужасной: голод, холод, болезни, но даже в этих условиях были люди, которые сострадали, сочувствовали, сердцем понимали несправедливость». 
«11 марта 1944 года прибыли вместе с сестрами (самой маленькой было 9 месяцев) и маленьким братом (4 года) в Восточный Казахстан. Они никогда не видели столько снега - полтора метра. На санях их привезли в районный центр Предгорный». Тетя Залва вспоминала: «Стали спрашивать, кто мы, откуда, кто взрослые, кто родители. Я хорошо владела русским языком, рассказала, что мать и брат работали на военном заводе, отец на фрронте. Показала последнее письмо, которое он прислал с фрронта. Они задали нам и себе вопрос: За что вас выселили? Многие люди недоумевали. Логика жизни не укладывалась в выдумку о «чеченцах-бандитах». Пригласили уборщицу конторы. Затопили баню, искупали нас. Столько было вшей! Накормили молоком и хлебом. Утром вызвали председателя колхоза, нас устроили в колхозный детский сад. Обуть и одеть было нечего. Иногда к Иртышу приходилось бегать за водой по снегу босиком».

В 1945 году Марьям Мусаева прибыла на станцию Предгорная Восточного Казахстана. Ее обнаружили в одном из вагонов с углем и выкинули на ходу. Она искала своих шестерых детей, вывезенных из Чечни в далекий холодный край. Ее отправили в Южный Казахстан, детей - в Восточный. Год и шесть месяцев, день и ночь, металась она от одной станции к другой - с большим трудом удавалось упросить проводников - подсаживалась в вагоны с углем, без теплой одежды и куска хлеба. Вот что вспоминает ее дочь Залва: «От станции Предгорная до села Глубокое мама ночью прошла более 10 километров. Когда пришла, она услышала мелодию чеченской песни. Ее ноги сами понесли. Подошла к избушке, где мы остановились, заглянула в окно, у которого горела лампада, и узнала свою «бохча» (мешочек с швейными принадлежностями) и швейную машину «Зингер». Постучала и упала, дальше двигаться не было сил. К этому времени нас уже нашел отец, который приехал чуть раньше с фронта. Он услышал стук в окно, вышел - под окном лежит мама. Занесли в дом, ее невозможно было узнать: вся черная от угольной пыли».

Люди на новом месте отказывались строить жилье, сажать огороды, надеясь, что через неделю, месяц, год вернутся на кавказскую землю, что справедливость будет вот-вот восстановлена. Но прадедушка начал строить дом, посадил сад. Люди приходили, любовались, удивлялись. Такой положительный пример помог многим выжить в суровых условиях. Выращенные овощи и фррукты он раздавал больным и престарелым. Те, кто не хотел строить и сажать, приходили за семенами и саженцами, просто за советом... Цветущий уголок рядом с жильем напоминал изобильную кавказскую землю» (Мальцагова, 2014).

Депортация ингушей, февраль 1944 года. Воспоминания Мазиевой Ашат Ильясовны, 1931 года рождения, Карагандинская область, Осакаровский район, с. Тельманское. Нас переселили всей семьей, но отца с того времени мы не видели. Его куда-то увели 23 февраля, вытащили из дома полураздетого; спустя какое-то время нам сообщили, что его расстреляли. Мы жили в селе Экажево, Чечено-Ингушской АССР. В конце 1943 года к нам в село стали съезжаться представители НКВД, солдаты ходили в форме. По селу прошел слух о том, что готовится процесс депортации ингушей. Хотя все прекрасно знали, что в 1943 году депортировали карачаевцев, но все верили в лучшее и думали о том, что наш народ эта участь не постигнет. Но вот наступило 23 февраля 1944 года. Нам сказали собираться, что дают 24 часа на сборы. Мы начали плакать. Мама спрашивала, куда мы поедем. Ей очень грубо ответили, толкнули. Сказали, что поедете умирать с голоду, если доберетесь, 
конечно. Мы стали в спешке собирать вещи. Набрали мешок кукурузы, муки, картошку, еще что-то уже не помню. Вещей побольше на себя надели. Старшая сестра помогала маме, собирала младших, они все хныкали. На следующий день пришли за нами. Сопротивления никто не оказывал: все боялись, что убьют. Мама нам так и сказала, чтоб как мыши себя вели. Мы видели, как женщина одна хотела убежать, ее мужчина в форме ударил, прям по лицу, она и упала на землю. На момент переселения нас было 7 человек в семье. Мама, ее звали Зульфия, нас детей в семье было 6. Самой старшей была сестра Элина 1930 года, после нее шла я, потом брат 1933 года, Газиз, после брата сестренка Хадижа 1937 года и самому младшему брату было всего 3 месяца, он 1943 года, его Гасар звали, он умер в дороге, от голоду. Помню, как мама плакала. Мама в дороге ничего не ела, у нее молоко и пропало. И умер малыш. Пришли конвойные обыскали вагон и выкинули его на обочину. Это не было редкостью тогда, с нами обращались как с животными. Для нашего народа постыдно не хоронить тела умерших, но обстоятельства вынудили.

После того как нас собрали всех в центре села, погрузили в грузовики, затолкали всех и отвезли на станцию, не помню, как она называется. Там нас распределили по вагонам, брата хотели в другой вагон посадить, но мама умоляла, чтоб он с нами поехал. В итоге она заплатила какие-то деньги. И брату разрешили ехать с нами в одном вагоне. Ехали мы дорогой очень сложно, вся вот эта вот дорога была без преувеличения сказать обсыпана трупами. Люди с голода умирали. И не давали, не только хоронить, но и даже попрощаться. Многие прятали в вагонах умерших. Проходил конвой обнаруживал, еще наказывал их, выбрасывали тела на ходу. Пищей, что захватили с собой, люди делились в вагоне, чтобы выжить, разрешали на остановках немного запастись дровами, углем, водичку давали, а с продуктами дело было сложно. Вот в таком ужасном положении нас везли к месту прибытия. Вот так я в свои 13 лет стала «врагом» народа. Нас привезли в Казахстан, в Карагандинскую область, Нуринский район, село Заречное. Местные жители приняли нас хорошо, благодаря им мы и выжили. Все готовы были поделиться куском хлеба. Они тоже не очень-то богато жили. Они жили даже хуже, чем мы у себя на родине. Первую зиму местное население принимали нас в своих домах. А потом летом уже строили жилье. Местное население жило в землянках. Нас всех отправили работать в колхоз, писали трудодни. Ничего нам не платили. Давали хлеб, похлебки какие-то. И все. Весной, правда, пожалели нас и дали корову и двух баранов. Вот этим и кормились. Корову доили. Стали огород сажать. А денег не было, средств к существованию не было тоже. Мы оказались в пустой степи. И если бы нас не приютили местные жители, то умерли бы все.

Привезенная обувь из Ингушетии не подходила по сезону и быстро сносилась. О покупки обуви не могло идти и речи. Поэтому приходилось делать обувь самим. Так же ходили в чунях. Их изготавливали следующим образом. Сначала снимали шкуру с ноги коровы и сушили её. Затем туда ставили ногу и вокруг неё пробивали дырки, которые связывали шнуром или проволокой. Вместо стелек клали солому и носили несколько сезонов. Или просто обматывали кусок шкуры вокруг ноги и спереди связывали веревкой. Потом начали стричь овец и из шерсти вязать носки, делать стельки. Женщины валяли кошму. Из бараньих шкур делали различные головные уборы, одежду, чтобы хоть как-то утеплиться. Хотя изначально дети сидели целый день дома 
под кусками ткани, так как не было одежды. Женщины и мужчины носили мешки, в которых делались вырезы для рук и также для ног.

Все мы хотели кушать. Родители не подавали виду, как им было тяжело, глядеть на своих голодных детей. Перед отъездом в Казахстан мама набрала кукурузы в мешок, которую мы потом и ели. У нас уже было тепло тогда, все таяло, грязь была. При погрузке в вагоны все мы были грязные и от этого заводились вши. После прибытия в казахскую степь лица от холода и ветра покрывались болячками, которые долгое время не заживали и кровоточили. Лекарств обработать раны не было, да и речи об аптеке не могло и быть. Спустя время уже распространялся тиф по всей степи и люди умирали, как мухи. Помню, нас каждый день выгоняли на различные работы. И в один день семья ингушей не вышла на работу, оказалось, что они все умерли. Просто замерзли. Не было лекарств. Люди умирали как мухи. Целыми семьями от голода. А хоронить не могли. Ни лопат, ни ломов. В снег зарывали зимой, когото волки съедали. Вещи стирали и люди мылись при помощи золы и песка. А больше ничего и не было. У нас у всех были длинные волосы и у всех завелись вши. Помню, как голова чесалась.

Сажали огороды, картофель. Там, где мы находились, неплохо урожай картофеля собирали, капусту и другие овощи. Какие-то запасы зимние делали и т.д. Потом была возможность держать корову, кур и т.д.

Отправили нас в школу, а я русский язык вообще не знала, большая ходила, меня в первый класс посадили. Многие смеялись. Но учителя хорошие были. Все понимали. Время прошло, и мы постепенно начали учиться русскому языку. В семье мы разговаривали только на родном языке. Мы и на чужой земле продолжали свои религиозные традиции, читали намаз, держали уразу. Хотя за это строго наказывали, если узнают и посадить могли. Несмотря на то, что было очень тяжело, люди были намного лучше и добрей чем сейчас, человечнее. Спустя пару лет после депортации, после того как мы обжились, каждую неделю стали устраивали вечера с национальными танцами, на который собиралась ингушская молодежь. С каждой девушкой обязательно приходил или родной или двоюродный брат, это был настоящий отдых.

Мы прибыли в Казахстан, в Казахскую ССР, я должна это сказать, это не только мое мнение, а мнение подавляющего большинства моего народа, ингушского народа, что многим даже приезжим, Казахстан стал второй родиной. А особенно тем, кто там родился, вырос, это вообще их родина. И мы с большой благодарностью, чувством братства, с чувством доброго желания относимся к казахскому народу. Эта земля, эта страна долгие годы, всю жизнь нас кормила, нас приютила, многое мы там набрали себе хорошего, доброго, поэтому мы с большой благодарностью, с братским чувством относимся и к Казахстану и казахскому народу (Интервью с Мазиевой, 2019).

Заключение. Данные фррагменты женских воспоминаний позволили отметить еще ряд некоторых общих закономерностей. Первая из них - это кажущаяся обыденность с которой женщины говорили о смерти, в том числе и близких людей. И эта обыденность, констатация множества смертей - не свидетельство черствости, а принятия неизбежности происходящего, примирения с ним. Психологи отмечают, что объективность потери, утраты сопровождается субъективной переработкой полученной трагической информации. Мысли, чувства и переживания людей, перенесших утрату, индивидуальны, уникальны и неповторимы. Психологи определяют горе как реакцию на утрату значимого объекта, утрату части собственной идентичности или ожидаемого будущего. Реакция утраты на смерть близкого человека может 
проявляться эмоциональным шоком с оцепенением и «окаменелостью» или беспокойством, плачем, нарушением сна, аппетита, сужением сознания на психотравмирующих переживаниях, постоянными воспоминания об умершем, душевной тоской и т.п. Но депортированные женщины не могли бы выжить, а главное, спасти своих детей, семью, если бы не «окаменели», не «привыкли» к смерти. Как много в этих текстах фррагментов о смертях: «в первые месяцы умирало очень много людей, особенно детей»; «хоронили родных и близких в степи, не имея возможности поставить крест, не из чего было»; «я видела, как умирают близкие и родные мне люди», «помню, как брат умер по пути в Казахстан», «его не похоронили», «его кости остались на холодной, чужой земле», «у тети умер грудной ребенок», «зимой с голоду пухли», «он все равно умер», «люди умирали», «просто мор был», «зимой хоронить нельзя», «рыли трактором ров общей братской могилы», «выдать умерших», «где их хоронили, мы не знаем», «старик не выдержал, умер по дороге», «поедете умирать с голоду, если доберетесь», «он умер в дороге, от голоду», «умер малыш», «выкинули его на обочину», «постыдно не хоронить тела умерших», «вот эта вот дорога ...обсыпана трупами», «люди с голода умирали», «не давали хоронить», «прятали в вагонах умерших», «выбрасывали тела на ходу», «люди умирали, как мухи», «семья ингушей все умерли, просто замерзли», «целыми семьями от голода», «хоронить не могли», «в снег зарывали зимой, кого-то волки съедали». Эти фрагменты - свидетельство адаптации женщин к смерти, ее простой констатации. Возможно, это отношение позволяло перестать ее боятся, стать к ней равнодушным или понимать безысходность положения и, хотя бы таким образом сохранить силы (жизнь).

И параллельно сохранились воспоминания, наполненные огромным теплом и благодарностью, причем они характерны именно для народов, депортированных в Казахстан. И женщины, независимо от национальности и возраста (были они взрослыми в период депортации или детьми), говорят с огромной благодарностью о своем отношении к казахам и казахстанцам в целом: «переселенцев местные жители не обижали, наоборот, старались хоть чем-нибудь помочь», «относились дружелюбно», «дружили, поддерживали отношения», «хозяева, у которых мы жили, были очень добрые люди и пытались нам всячески помочь», «семья, у которой жили, никогда нас не обделяла», «помощь казахского населения, которые оказывали всяческую поддержку», «спасибо, что приняли и приютили нас немцев и не дали нам умереть с голоду местные жители», «семья стариков, у которых мы жили первый год, дали нам телогрейку теплую», «никогда не садился за стол без нас», «он старался дать нам какие-нибудь вещи, ведь мы были почти раздетыми», «люди в деревне относились к нам по-доброму», «люди не были агрессивными», «потом уже были все вместе, уже не разделялись, где казахи, где украинцы, где русские, где немцы», «общее горе, оно как-то сплачивало людей», «даже в этих условиях были люди, которые сострадали, сочувствовали, сердцем понимали несправедливость», «накормили молоком и хлебом», «местные жители приняли нас хорошо, благодаря им мы и выжили», «все готовы были поделиться куском хлеба», «местное население принимали нас в своих домах», «весной, правда, пожалели нас и дали корову и двух баранов» и т.д. И не случайно Казахстан стал второй родиной для многих народов, перенесших сталинские репрессии. Для большинства советских людей была характерна жертвенность и сострадательность, но особенность казахского народа, его гостеприимство, способность поделиться достарханом с ближним, изменила ментальность почти всех живущих в республике людей, 
поэтому можно утверждать, что трагический путь депортированных народов, оказавшихся волею сталинских репрессий в Казахстане, хоть частично, но «скрашивался» добротой и гостеприимством казахов.

\section{Әдебиеттер тізімі / Список литературы}

1. Бугай, 2004 - Бугай Н.Ф. Депортация народов // Война и общество, 1941-1945 книга вторая. М.: Наука, 2004 // Электронный ресурc. URL: https://scepsis.net/library/id_1237.html (дата обращения 3.03.2019).

2. Бугай, 1995 - Бугай Н.Ф. Л. Берия - И. Сталину: «Согласно Вашему указанию...». М., 1995. 323 с. // Электронный ресурc. URL: https://ria.ru/society/20091114/193419498.html (дата обращения 4.03.2019).

3. Гусейнов, 2008 - Гусейнов Г. Язык и травма освобождения/ Новое литературное обозрение. 2008. №94. С. 130-147// Электронный ресypc.URL: http://magazines.russ.ru/nlo/ 2008/94/gg14.html (дата обращения 12.04.2019).

4. Гучинова, 2008 - Гучинова Э-Б. Язык травмы. Женские воспоминания о депортации калмыков и армян. 2008 // Электронный ресурc. URL: http://www.elzabair.ru/cntnt/lmenu/vystupleni/ yazyk_trav.html (дата обращения 12.03.2019).

5. Депортированные, 1998 - Депортированные в Казахстан народы: время и судьбы. Алматы: Арыс-Казахстан, 1998. 428 с.

6. Из истории депортации, 2014 - Из истории депортаций. Казахстан. 1935-1939 гг. Сборник документов. Алматы: LEM, 2014. 740 с.

7. Интервью с Мазиевой Ашат Ильясовной,(1931 г.р.), жительницей Карагандинской области записано Майлыбаевой Д. в 2019 г.

8. Интервью с Фиттель Ирмой (1927 г.р.), жительницей Карагандинской области записано Майлыбаевой Д. в 2019 г.

9. Земсков, 2005 - Земсков В.Н. Спецпоселенцы в СССР, 1930-1960. М.: Наука, 2005. 306 с.

10. Людтке, 1999 - Людтке А. «История повседневности» в Германии после 1989 года // Казус: индивидуальное и уникальное в истории. 1999. (вып. 2). М., 1999. С. 117-126.

11. Некрич, 1978 - Некрич А.М. Наказанные народы. Нью-Йорк, 1978. 173 с. // Электронный pecypc. URL: http://padaread.com/?book=91936\&pg=173(дата обращения 21.01.2019).

12. Полян, 2001 - Полян П. Не по своей воле... История и география принудительных миграций в CCCP. М., 2001. // Электронный ресурс. URL: http://old.memo.ru/history/deport/ (дата обращения 21.07.2018).

13. Солженицын, 1989 - Солженицын А. Архипелаг ГУлАГ. М.: Сов. писатель; Новый мир, 1989.

14. Сталинские, 2005 - Сталинские депортации. 1928-1953. Под общей редакцией академика А.Н.Яковлева. Составитель Н.Л.Поболь, П.М.Полян. Серия: Россия. XX век. Документы. М.: МФД, Материк, 2005. 904 с.

15. Народ выходил, 2016 - Народ выходил смотреть на нас: Фашистов везут. Краткая история этнических немцев в ГУЛАГе. Война / Медиазона. 16 ноября 2016 год // Электронный ресурс. URL: https://zona.media/article/2016/16/11/deutsch-2 (дата обращения 21.03.2019).

16. Чемодан историй, 2017 - Чемодан историй. Что помнят народы о депортации в Казахстан. 1 мая 2017 год // Электронный ресурc.URL: https://tengrinews.kz/article/520/ (дата обращения 3.04.2019).

17. Мальцагова, 2014 - Мальцагова М. «Бохча» моей бабушки. Семейные воспоминания о депортации 1944 - 1957.23 февраля 2014 //Электронныйресурс.URL: http://urokiistorii.ru/article/829 (дата обращения 13.04.2019)

18. Conquest, 1960 - ConquesR. Soviet Deportation of Nationalities. Macmillan, 1960. 203 p.

\section{References}

Bugaj, 2004 - Bugaj N.F. Deportaciya narodov // Vojna i obshchestvo, 1941-1945 kniga vtoraya. M.: Nauka, 2004 // Elektronnyj resurs. URL: https://scepsis.net/library/id 1237.html (data obrashcheniya 3.03.2019) (In Rus.)

Bugaj, 1995 - Bugaj N.F. L. Beriya - I. Stalinu: «Soglasno Vashemu ukazaniyu...». M., 1995. 323 s. // Elektronnyj resurs. URL: https://ria.ru/society/20091114/193419498.html (data obrashcheniya 4.03.2019)(In Rus.)

Gusejnov, 2008 - Gusejnov G. YAzyk i travma osvobozhdeniya/ Novoe literaturnoe obozrenie. 2008. №94. S. 130-147// Elektronnyj resurs.URL: http://magazines.russ.ru/nlo/2008/94/gg14.html (data obrashcheniya 12.04.2019)(In Rus.) 
Guchinova, 2008 - Guchinova E-B. YAzyk travmy. ZHenskie vospominaniya o deportacii kalmykov i armyan. 2008 // Elektronnyj resurs. URL: http://www.elzabair.ru/cntnt/lmenu/vystupleni/ yazyk_trav.html (data obrashcheniya 12.03.2019)(In Rus.)

Deportirovannye, 1998 - Deportirovannye v Kazahstan narody: vremya i sud'by. Almaty: ArysKazahstan, 1998. $428 \mathrm{~s}$.

Iz istorii deportacii, 2014 - Iz istorii deportacij. Kazahstan. 1935-1939 gg. Sbornik dokumentov. Almaty: LEM, 2014. 740 s.(In Rus.)

Interv'yu s Mazievoj Ashat Il'yasovnoj,(1931 g.r.), zhitel'nicej Karagandinskoj oblasti zapisano Majlybaevoj D. v 2019 g.(In Rus.)

Interv'yu s Fittel' Irmoj (1927 g.r.), zhitel'nicej Karagandinskoj oblasti zapisano Majlybaevoj D. v 2019 g.(In Rus.)

Zemskov, 2005 - Zemskov V.N. Specposelency v SSSR, 1930-1960. M.: Nauka, 2005. 306 s.(In Rus.)

Lyudtke, 1999 - Lyudtke A. «Istoriya povsednevnosti» v Germanii posle 1989 goda // Kazus: individual'noe i unikal'noe v istorii. 1999. (vyp. 2). M., 1999. S. 117-126.(In Rus.)

Nekrich, 1978 - Nekrich A.M. Nakazannye narody. N'yu-Jork, 1978. 173 s. // Elektronnyj resurs. URL: http://padaread.com/?book=91936\&pg=173(data obrashcheniya 21.01.2019)(In Rus.)

Polyan, 2001 - Polyan P. Ne po svoej vole... Istoriya i geografiya prinuditel'nyh migracij v SSSR. M., 2001. // Elektronnyj resurs. URL: http://old.memo.ru/history/deport/ (data obrashcheniya 21.07.2018)(In Rus.)

Solzhenicyn, 1989 - Solzhenicyn A. Arhipelag GULAG. M.: Sov. pisatel'; Novyj mir, 1989.(In Rus.)

Stalinskie, 2005 - Stalinskie deportacii. 1928-1953. Pod obshchej redakciej akademika A.N.YAkovleva. Sostavitel' N.L.Pobol', P.M.Polyan. Seriya: Rossiya. XX vek. Dokumenty. M.: MFD, Materik, 2005. 904 s. (In Rus.)

Narod vyhodil, 2016 - Narod vyhodil smotret' na nas: Fashistov vezut. Kratkaya istoriya etnicheskih nemcev v GULAGe. Vojna / Mediazona. 16 noyabrya 2016 god // Elektronnyj resurs. URL: https://zona.media/article/2016/16/11/deutsch-2 (data obrashcheniya 21.03.2019)(In Rus.)

CHemodan istorij, 2017 - CHemodan istorij. CHto pomnyat narody o deportacii v Kazahstan. 1 maya 2017 god // Elektronnyj resurs.URL: https://tengrinews.kz/article/520/ (data obrashcheniya 3.04.2019)(In Rus.)

Mal'cagova, 2014 - Mal'cagova M. «Bohcha» moej babushki. Semejnye vospominaniya o deportacii 1944-1957. 23 fevralya 2014 //Elektronnyjresurs.URL: http://urokiistorii.ru/article/829 (data obrashcheniya 13.04.2019)(In Russ.)

Conquest, 1960 - ConquesR. Soviet Deportation of Nationalities. Macmillan, 1960. 203 p. 